\title{
Cryopreservation of semen from goats fed a diet supplemented with flaxseed
}

\author{
Criopreservação de sêmen de caprinos alimentados com dieta suplementada com \\ semente de linhaça
}

SOUZA, Rosileia Silva ${ }^{1}$ (D); BARBOSA, Larissa Pires ${ }^{1} *$ (D); AGUIAR, Cristiane Silva ${ }^{1}$ (D); VIEIRA, Renan Luiz Albuquerque ${ }^{1} \mathbb{B}^{1}$; RIBEIRO, Márcio Oliveira ${ }^{1}{ }^{\mathbb{D}}$; ARAÚJO, Raísa Cordeiro dos Santos Alves de ${ }^{1}$ D; ; SILVA, Mariana Alves de Andrade ${ }^{1} \mathbb{D}^{\mathbb{D}}$; SANTANA, Ana Lúcia Almeida ${ }^{1}$

${ }^{1}$ Universidade Federal do Recôncavo da Bahia (UFRB), Centro de Ciências Agrárias, Ambientais e Biológicas, Cruz das Almas, Bahia, Brasil.

*Autora para correspondência: larissa@ ufrb.edu.br

\begin{abstract}
The objective of this study was to evaluate the effects of the inclusion of flaxseed in the diet of male goats on the resistance of semen to the cryopreservation process. Sixteen males were distributed in four groups and fed a diet supplemented with 0 , 4,8 , and $12 \%$ of flaxseed for a period of 60 days. Only the ejaculates that presented motility and vigor above $70 \%$ and 3 , respectively, were sent through the cryopreservation process. After thawing, the semen was evaluated through thermo resistance, hypoosmotic, and acrossomal integrity tests. The data were submitted to analysis of variance and regression at 5\% of significance. There was positive quadratic behavior for motility after 60,120 , and 180 min in the thermoresistance test (TTR), and positive quadratic behavior for sperm vigor after thawing after 120 and $180 \mathrm{~min}$ in the TTR ( $\mathrm{P}<0.05)$. However, negative quadratic behavior was obtained for plasma membrane integrity according to the hypoosmotic test $(\mathrm{P}<0.05)$ and there was a difference in the acrosomal integrity test, presenting an optimum maximum level of $3.25 \%$ of flaxseed for acrosomal integrity of $65.83 \%$ ( $\mathrm{P}<0.05)$. The results obtained demonstrated that the addition of as much as $12 \%$ of flaxseed to the diet of goat breeders improved post-thawing sperm quality.
\end{abstract}

Keywords: alpha-linolenic acid, cryopreservation, Linum usitatissimum, omega 3

\section{RESUMO}

O objetivo com o estudo foi avaliar o efeito da inclusão de semente de linhaça na dieta de machos caprinos sobre a resistência do sêmen frente ao processo de criopreservação. Foram utilizados 16 machos, os quais foram distribuídos em quatro grupos e receberam dieta suplementada com $0,4,8$ e $12 \%$ de semente de linhaça, durante um período de 60 dias. As coletas de sêmen iniciaram 25 dias após o início do fornecimento das dietas. Apenas os ejaculados que apresentaram motilidade e vigor acima de $70 \%$ e 3, respectivamente, foram encaminhados para o processo de criopreservação. Após o descongelamento, o sêmen foi avaliado através dos testes de termorresistência, hiposmótico e de integridade acrossomal. Os dados foram submetidos à análise de variância e regressão a $5 \%$ de significância. Houve comportamento quadrático positivo para a motilidade progressiva aos 60, 120 e 180 minutos no teste de termoresistência (TTR), e comportamento quadrático positivo para o vigor espermático pós-descongelamento aos 120 e 180 minutos no TTR $(\mathrm{P}<0,05)$. Entretanto, obteve-se comportamento quadrático negativo para a integridade da membrana plasmática pelo Teste Hiposmótico $(\mathrm{P}<0,05)$ e houve diferença para o teste de integridade acrossomal, apresentando nível máximo ótimo de 3,25\% de semente de linhaça para integridade acrossomal de $65,83 \% \quad(\mathrm{P}<0,05)$. Os resultados obtidos demonstram que a adição de $12 \%$ de semente de linhaça na dieta de

\section{Animal Reproduction}


reprodutores caprinos melhora a qualidade espermática pós-descongelamento.
Palavras-chave: ácido alfa-linolênico, criopreservação, Linum usitatissimum, ômega 3 


\section{INTRODUCTION}

For many years, most goat artificial insemination programs have been conducted using fresh or cooled semen. According to Severo (2009), the use of cooled semen keeps maintains the number of viable sperm longer than does the use of fresh semen; however, sperm viability begins to decrease after $72 \mathrm{~h}$ of storage. In view of this, the used of frozen semen is considered an alternative to the use of fresh and cooled semen, because according to Silva \& Guerra (2011) it increases the life span of the ejaculate. However, Barros \& Toniolli (2011) pointed out that the cryogenic process causes damage to sperm cell structure, which results in reduced sperm motility and survival time in the female reproductive system.

It is believed that dietary supplementation with energy sources can positively assist the cryopreservation process, because, according to Pimentel et al. (2005), the omega-3 fatty acid intake promotes structural and functional changes in the phospholipid membrane, and consequently, increases the cell membrane fluidity, allowing greater protein mobility, and favoring greater transduction signal exchange, hormonereceptor interaction, and substrate transport between intra- and extracellular media.

In this sense, flaxseed is an excellent source of polyunsaturated fatty acids (PUFAs) and a possible alternative to increase reproductive rates. According to Morris et al. (2003), the flaxseed lipid composition contains saturated fatty acids (9\%), moderate amounts of monounsaturated fatty acids (18\%), and a high concentration of PUFAs (73\%), in particular omega-3. Thompson et al. (1991) indicated that the relationship between omega- 3 and omega- 6 series fatty acids may be the main reason for the increase in fresh semen quality because sperm membrane fluidity is directly related to its lipid composition. Therefore, the objective of the study was to evaluate the effects of the inclusion of flaxseed in the diet of male goats on the resistance of semen to the cryopreservation process.

\section{MATERIAL AND METHODS}

The research was conducted in July and October at the Cruzeiro do Mocó Experimental Station belonging to the Bahian Company of Agricultural Development (EBDA) located in the city of Feira de Santana-BA $\left(12^{\circ} 16^{\prime} 00^{\prime \prime} \mathrm{S}\right.$ and $\left.38^{\circ} 58^{\prime} 00^{\prime \prime} \mathrm{W}\right)$ at 234 meters above sea level. The location has an average temperature of $26.5^{\circ} \mathrm{C}$ and average rainfall ranging from 900 to $1,200 \mathrm{~mm}$ annually (UEFS Climatological Station 83221INMET/DTEC). The procedures performed in this study were submitted, evaluated, and approved by the Animal Use Ethics Committee (CEUA) of the Federal University of Recôncavo da Bahia (nº 23007.006635 / 2014-60).

Sixteen Saanen male goats clinically healthy and sexually mature were used in this study, having age and initial live weight of $2.12 \pm 084$ years and $39.34 \pm$ $16.72 \mathrm{~kg}$, respectively, and final weight of $48.17 \pm 5.21 \mathrm{~kg}$. The animals were previously submitted to an andrological examination, following the norms of the Brazilian College of Animal Reproduction (CBRA, 2013). The animals were then randomly assigned to four treatments: T1 - no flaxseed diet supplementation, and $\mathrm{T} 2, \mathrm{~T} 3$, and $\mathrm{T} 4$ dietary supplementation with 4,8 , and $12 \%$ flaxseed diet, respectively, based on dry matter. The animals were maintained in four $16 \mathrm{~m}^{2}$ collective 
stalls that were suspended with wooden slatted floors and fiber-cement roof coverings. Goats were provided drinking and feeding troughs.

The diets were formulated according to the NRC (2007) (Table 1) and provided twice a day for a period of 60 days. The supply was made to provide 10-20\% leftovers while maintaining a 60:40 roughage: concentrate ratio as a complete mixture. The roughage supplied was Tifton-85 (Cynodon sp.) hay ground into an approximately $5 \mathrm{~cm}$ particle size. Water was provided ad libitum. The leftovers were quantified and collected daily to allow for the necessary adjustments.

Table 1. Proportion of experimental diet ingredients based on dry matter

\begin{tabular}{lcccc}
\hline \multirow{2}{*}{ Ingredients } & \multicolumn{4}{c}{ Flaxseed Level $(\%)$} \\
\cline { 2 - 5 } & 0 & 4 & 8 & 12 \\
\hline Flaxseed & 0.00 & 4.00 & 8.00 & 12.00 \\
Minerals & 1.20 & 1.20 & 1.20 & 1.20 \\
Soybean meal & 11.20 & 9.30 & 7.40 & 5.52 \\
Corn Bran & 27.20 & 25.10 & 23.00 & 20.88 \\
Urea & 0.40 & 0.40 & 0.40 & 0.40 \\
Hay & 60.00 & 60.00 & 60.00 & 60.00 \\
Total & 100 & 100 & 100 & 100 \\
\hline
\end{tabular}

The bromatological composition of the experimental diets (Table 2) was performed according to the Association of Official Analytical Chemists AOAC (1990) to determine the dry matter, mineral matter, crude protein, and extract ethereal. The analyses for the determination of neutral detergent fiber and acid detergent fiber, cellulose, hemicellulose, and lignin were conducted according to Van Soest et al. (1991).

Table 2. Bromatological composition of experimental diets used in goat feeding

\begin{tabular}{lccccc}
\hline \multirow{2}{*}{ Nutrients (DM\%) } & \multicolumn{4}{c}{ Flaxseed Level $(\%)$} & \multirow{2}{*}{ Hay } \\
\cline { 2 - 5 } & 0 & 4 & 8 & 12 & \\
\hline Dry matter & 100.00 & 100.00 & 100.00 & 100.00 & 89.47 \\
Mineral matter & 4.82 & 4.39 & 4.52 & 4.21 & 4.27 \\
Crude protein & 24.59 & 24.43 & 22.35 & 23.36 & 2.17 \\
Extract ethereal & 2.16 & 6.07 & 9.87 & 12.93 & 0.71 \\
Neutral detergent fiber & 32.71 & 31.28 & 28.24 & 47.22 & 76.96 \\
Acid detergent fiber & 6.65 & 8.10 & 8.49 & 10.97 & 41.32 \\
Lignin & 1.58 & 1.71 & 2.35 & 3.07 & 8.56 \\
Cellulose & 5.07 & 6.39 & 6.14 & 7.90 & 32.76 \\
Hemicellulose & 26.06 & 23.18 & 19.74 & 36.25 & 35.64 \\
Non-fibrous Carbohydrates & 35.71 & 33.83 & 35.02 & 12.28 & 15.88 \\
\hline
\end{tabular}

Ejaculate collections began 25 days after the beginning of the diet treatments and were performed by the artificial vagina technique twice a week, totaling 10 viable collections per 
animal, using a female in estrus as a dummy and respecting a two-day interval between the collections. The ejaculates obtained in the collections were placed in a water bath at $37^{\circ} \mathrm{C}$ and submitted to physical and morphological examination (ejaculate volume, seminal appearance, mass motility sperm, progressive sperm motility, sperm vigor, sperm concentration, and major, minor, and total defects) using Phase Differential Interference Microscopy (Olympus ${ }^{\mathrm{TM}}$, Tokyo, Japan). Only samples with motility $\geq 70 \%$ and sperm vigor $\geq 3$ (CBRA, 2013) were submitted to the cryopreservation process.

The selected ejaculates were pre-diluted 1:1 with a citrate-yolk based diluent and 7\% glycerol, previously heated in a $37^{\circ} \mathrm{C}$ water bath. A final dilution was made to obtain 150 million sperm per inseminating dose using $0.25 \mathrm{~mL}$ straws. Subsequently, the semen was cryopreserved in a TK $3000^{\mathrm{TM}}$ freezing machine (TK Technology in Freezing, Ltd.) in two steps. The first step referred to the positive curve (cooling by $0.25^{\circ} \mathrm{C} / \mathrm{min}$ until reaching $+5^{\circ} \mathrm{C}$ starting at $32^{\circ} \mathrm{C}$ ) and the second step concerned the negative curve and was divided into two phases: freezing from $+5^{\circ} \mathrm{C}$ at a speed of $10^{\circ} \mathrm{C} / \mathrm{min}$ and $5^{\circ} \mathrm{C} / \mathrm{min}$ to $-120^{\circ} \mathrm{C}$. At the end of freezing, the straws were submerged in liquid nitrogen, packed in racks and stored in cryogenic cylinders.

To evaluate the cryopreserved semen, one straw was thawed from each match in a $37^{\circ} \mathrm{C}$ water bath for $30 \mathrm{~s}$, placed in polyethylene microtubes, and subsequently evaluated for the parameters of progressive sperm motility and sperm vigor, according to the values recommended by CBRA (2013) for cryopreserved semen.

The matches were evaluated by the thermoresistenic test (TTR). They were incubated for $180 \mathrm{~min}$ in a $37^{\circ} \mathrm{C}$ water bath, such that at $0,5,60,120$, and 180 min of this period, the progressive motility (0 to $100 \%)$ and sperm vigor (0 to 5) was observed by phase contrast microscopy. The functional integrity of the plasma membrane was evaluated for both fresh and frozen semen using the hypoosmotic test (HO) using $1 \mathrm{~mL}$ of fructose-containing hypoosmotic solution (100 mOsmol/kg) plus $10 \mu \mathrm{L}$ of semen from each start and incubated for $30 \mathrm{~min}$ in a water bath at $37^{\circ} \mathrm{C}$. For HO quantification, 200 sperm cells were classified by phase contrast microscopy with 1000-fold magnification for the presence or absence of bent tails. The number of HO-reactive sperm was calculated using the formula: $\mathrm{HO} \%=$ (\% tail changes after $\mathrm{HO})$ - (\% tail changes before HO). For calculus determination, all tail changes, whether or not associated with defects in another region of the sperm, were computed before and after $\mathrm{HO}$.

For the acrosomal integrity test, an aliquot of $10 \mu \mathrm{L}$ of fresh semen was added to $10 \mu \mathrm{L}$ of Pope - Fast Green/Rose Bengal Simple Dye and incubated for $70 \mathrm{~s}$. After this period, an aliquot was deposited on a slide to prepare a smear, which was evaluated under a 1000-fold light microscope. A total of 200 cells were counted, which were classified as 1) Healthy Acrosome: Lilac Stain or 2) Non-Healthy Acrosome: Pink Stain.

Data were subjected to an analysis of variance and regression analysis, adopting the $5 \%$ level of significance, using the statistical software of predictive analysis (SPSS 13.0).

\section{RESULTS AND DISCUSSION}

Dietary supplementation with flaxseed did not influence the progressive sperm motility of fresh semen $(P>0.05)$ and 
obtained an average (84.34\%) within the minimum limits recommended by CBRA (2013) for fresh semen.

Likewise, there was no significant difference for progressive post-thawing sperm motility $(24.38 \%)$ and for postthaw motility at $5 \mathrm{~min}$ in the TTR $(23.15 \%)$ (P > 0.05) (Table 3). The results obtained for post-thawing motility were not within the range indicated by the Brazilian College of Animal Reproduction (2013), which should be equal to or greater than $30 \%$, and this fact can be attributed to the cryopreservation process, corroborating the suggestion made by Barros \& Toniolli (2011), who stated that the cryogenic process causes damage to sperm cell structure and the consequence of this damage is the reduction of sperm motility. According to Ceylan \& Serin (2007), the reduction in sperm motility may be a result of membrane lipid peroxidation, which will reduce fecundation capacity in mammals. According to Chakrabarty et al. (2007), a significant loss of PUFAs present in the plasma membrane has a negative correlation with sperm motility.

Table 3. Feed consumption and progressive sperm motility post-thawing and in the cryopreserved semen thermoresistance test of male goats fed flaxseed levels

\begin{tabular}{|c|c|c|c|c|c|}
\hline & \multicolumn{4}{|c|}{ Flaxseed Level (\%) } & \multirow{2}{*}{$\begin{array}{c}\text { Regression } \\
\text { equation }\end{array}$} \\
\hline & 0 & 4 & 8 & 12 & \\
\hline $\begin{array}{l}\text { Average } \\
\text { consumption } \\
\text { (Kg/dia) }\end{array}$ & $4.83 \pm 0.44$ & $4.89 \pm 0.58$ & $4.51 \pm 0.40$ & $4.71 \pm 0.45$ & $\hat{Y}=4.75$ \\
\hline \multicolumn{6}{|c|}{ Progressive sperm motility } \\
\hline Fresh semen & $84.10 \pm 9.55$ & $85.44 \pm 10.26$ & $85.66 \pm 9.74$ & $82.15 \pm 10.14$ & $\hat{\mathrm{Y}}=84.33$ \\
\hline Post-thawing & $22.36 \pm 16.76$ & $18.94 \pm 17.89$ & $23.92 \pm 15.46$ & $32.30 \pm 18.22$ & $\hat{Y}=24.38$ \\
\hline TTR 5' & $19.53 \pm 13.56$ & $20.11 \pm 18.82$ & $23.70 \pm 14.97$ & $29.25 \pm 18.08$ & $\begin{array}{l}\hat{\mathrm{Y}}=23.14 \\
\hat{\mathrm{Y}}^{* *}=13.809-\end{array}$ \\
\hline TTR 60' & $13.93 \pm 10.91$ & $10.61 \pm 12.77$ & $14.11 \pm 12.04$ & $22.00 \pm 16.41$ & $\begin{array}{l}1.4091 \mathrm{x} \\
+0.1752 \mathrm{x}^{2} \\
\mathrm{R}^{2}=0.9958 \\
\hat{\mathrm{V}} * *-709\end{array}$ \\
\hline TTR 120' & $7.23 \pm 8.17$ & $2.16 \pm 3.38$ & $5.14 \pm 9.07$ & $13.55 \pm 12.20$ & $1.979 x+0.2106$ \\
\hline & & & & & $\begin{array}{l}\mathrm{R}^{2}=0.9951 \\
\hat{\mathrm{V}} * *-3743\end{array}$ \\
\hline TTR 180' & $3.78 \pm 5.64$ & $0.44 \pm 1.19$ & $1.46 \pm 3.23$ & $6.10 \pm 8.23$ & $\begin{array}{l}1.2968 x \\
+0.1247 x^{2}\end{array}$ \\
\hline & & & & & $\mathrm{R}^{2}=0.9986$ \\
\hline Loss of motility & $61.73 \pm 17.85$ & $66.50 \pm 23.40$ & $61.74 \pm 14.70$ & $49.85 \pm 18.43$ & $\begin{array}{l}2.1138 \mathrm{x}- \\
0.2603 \mathrm{x}^{2} \\
\mathrm{R}^{2}=0.9981\end{array}$ \\
\hline
\end{tabular}

TTR $=$ Thermoresistance Test. Data were analyzed by Regression Analysis at 5\% significance and refer to means \pm standard deviation. ** Significant at $5 \%$ significance. 
The results of the present study differed from those obtained by Blesbois et al. (1997), where supplementation of adult birds with diets containing omega-3 or omega- 6 sources altered the composition of long-chain PUFAs in sperm. In this study, dietary lipid enrichment resulted in significant differences in the n- $6 / n-3$ ratio in sperm and seminal plasma. In addition, the groups supplemented with the omega-3 source presented a lower n-6 / n-3 ratio and higher fertilization capacity. The latter may be caused by an increase in sperm viability in the female's genital system and/or its ability to fuse, because there is a change in sperm membrane structure, fluidity and/or, susceptibility to peroxidative damage.

When used directly as cryopreservation medium components, the sources of fatty acids proved to be beneficial to sperm post-thawing. Ansari et al. (2012) reported that the addition of an n-3 series fatty acid source to the goat semen diluent promoted increased postthawing sperm motility and attributed the result to the possible incorporation of DHA into the sperm cell membranes, especially in the sperm cell region tail, which would provide better fluidity and flexibility, and consequently improved progressive motility. In agreement with these findings, Machado et al. (2018) worked with doses of a fish oil source associated with ascorbic acid directly in the goat semen cryopreservation diluent and found a difference for progressive post-thawing sperm motility (68.33\%), which showed increasing linear behavior with beneficial effects in relation to the cryopreservation process, and consequently, in the post-thawing seminal quality. Dolatpanah et al. (2008) also worked with goats and provided four dietary treatments, including a $2.5 \%$ fish oil, a source of omega-3, and/or vitamin E (0.30 g / kg), and a control group. These authors reported a difference in progressive motility in this study, in which the best result was achieved with the use of fish oil $(83.72 \%)$.

In the present study, a positive quadratic behavior was obtained for progressive motility at 60, 120, and $180 \mathrm{~min}$ in the TTR $(\mathrm{P}<0.05) \quad$ (Table 3), demonstrating that the addition of flaxseed to the diet promoted greater cell resistance to sperm during the freezing/thawing process, proven by the greater sperm motility, up to $180 \mathrm{~min}$, for the treatment with the highest level of flaxseed (12\%). The reduction of motility in the other treatments corroborates the considerations of Purdy (2006), who stated that the semen cryopreservation process promoted a reduction in motility, membrane integrity, and semen fertilizing capacity. Abd El-Razek et al. (2009) worked to include source levels of omega-3 (fish oil) into sheep diets and suggested that increasing sperm membrane DHA content via lipid supplementation may improve membrane fluidity, and thus, increase membrane resistance of sperm to damage caused by refrigeration and freezing/thawing.

Dolatpanah et al. (2008) further stated that PUFAs contributed to greater membrane fluidity, flexibility, acrosome integrity, and membrane-bound receptors. In addition, PUFAs are the precursors of prostaglandins and leukotrienes, being important in sperm motility.

Because the loss of motility is proportional to the progressive motility behavior, a negative quadratic behavior was obtained for the loss of motility in the TTR $(\mathrm{P}<0.05)$ (Table 3), with less motility loss for the group with the inclusion of $12 \%$ flaxseed in the diet. The possible reason for the results may 
be caused by cell preservation, perhaps by incorporating fatty acid into the membrane, promoting greater resistance to the cryopreservation process, and promoting a reduction in lipid peroxidation, which increases during the semen cryopreservation process. Ansari et al. (2012), in studies with inclusion of n-3 PUFAs and antioxidant levels directly in the diluent, before and after the freezing process, and observed better results for sperm motility and viability with the highest inclusion levels in goat semen.

The inclusion of flaxseed levels in the goat diet did not change the sperm vigor of fresh and post-thawed semen ( $\mathrm{P}>$ $0.05)$, with an average of 4.78 and 1.80 , respectively (Table 4). Post-thawing average vigor does not meet the minimum requirements required by CBRA (2013), which suggests that goat semen after thawing should remain at least a vigor of 2 , which was observed only in the $12 \%$ flaxseed treatment group $(2,17)$. The results of the present study are in agreement with those of Machado et al. (2018) who did not obtain significant differences for postthawing progressive vigor with the inclusion of fish oil and ascorbic acid in the extender in goat semen.

Table 4. Post-thawing sperm vigor of goats fed flax seed levels.

\begin{tabular}{|c|c|c|c|c|c|}
\hline \multirow{2}{*}{ Sperm vigor } & \multicolumn{4}{|c|}{ Flaxseed Level (\%) } & \multirow{2}{*}{ Regression equation } \\
\hline & 0 & 4 & 8 & 12 & \\
\hline Fresh semen & $4.70 \pm 0.53$ & $4.72 \pm 0.46$ & $4.87 \pm 0.32$ & $4.85 \pm 0.58$ & $\hat{\mathrm{Y}}=4.78$ \\
\hline Post-thawing & $1.58 \pm 1.25$ & $1.61 \pm 1.52$ & $1.85 \pm 1.22$ & $2.17 \pm 1.12$ & $\hat{Y}=1.80$ \\
\hline TTR 5' & $1.50 \pm 1.08$ & $1.58 \pm 1.49$ & $1.81 \pm 1.20$ & $1.97 \pm 1.08$ & $\hat{\mathrm{Y}}=1.71$ \\
\hline TTR 60' & $0.95 \pm 0.80$ & $0.69 \pm 0.73$ & $1.07 \pm 0.93$ & $1.42 \pm 1.05$ & $\begin{array}{l}\hat{Y}=1.03 \\
\hat{Y} * *=0.523-\end{array}$ \\
\hline TTR 120' & $0.55 \pm 0.69$ & $0.19 \pm 0.34$ & $0.46 \pm 0.73$ & $0.82 \pm 0.61$ & $\begin{array}{l}0.108 \mathrm{x}+0.0113 \mathrm{x}^{2} \\
\mathrm{R}^{2}=0.928 \\
\hat{\mathrm{Y}} * *=0.141-\end{array}$ \\
\hline TTR 180' & $0.16 \pm 0.30$ & $0.00 \pm 0.00$ & $0.18 \pm 0.31$ & $0.32 \pm 0.37$ & $\begin{array}{l}0.0398 x+0.0047 x^{2} \\
R^{2}=0.8598\end{array}$ \\
\hline Loss of vigor & $3.11 \pm 1.28$ & $3.11 \pm 1.72$ & $3.01 \pm 1.25$ & $2.47 \pm 1.00$ & $\hat{\mathrm{Y}}=2.92$ \\
\hline
\end{tabular}

Goats supplemented with $0,4,8$ and $12 \%$ flaxseed in the diet. Data were analyzed by Regression Analysis at 5\% significance and refer to means \pm standard deviation. ** Significant at 5\% significance.

There was no significant difference for sperm vigor at 5 and $60 \mathrm{~min}$ in the TTR, nor for sperm loss in the TTR $(\mathrm{P}>$ 0.05); however, the positive quadratic behavior for sperm vigor at 120 and 180 min in the TTR was obtained $(\mathrm{P}<0.05)$ (Table 4). The results in the TTR showed a linear decrease in sperm vigor over $2 \mathrm{~h}$ of the test, with a loss of 3.11, corroborating the data reported by Silva et al. (2006), which achieved a linear drop over $2 \mathrm{~h}$ when evaluating thawed goat semen departures. Sudheera et al. (1997) considered that dietary n-3 PUFAs may influence membrane fluidity and the action of enzymes necessary for the production of energy and many lipid-protein-dependent receptor functions, which would, therefore, promote better sperm vigor, but this was not the result obtained in this study. Sperm vigor was directly related to motility and although positive quadratic behavior for progressive motility occurred at 60, 120, and 180 min, the same behavior for vigor was observed only at 120 and 180 min, with better results in the treatment group with $12 \%$ flaxseed. 
The supplementation of flaxseed in the goat diet promoted negative quadratic behavior for plasma membrane integrity $(\mathrm{P}<0.05)$ (Table 5). The results obtained through the hypoosmotic test showed that a level of $8.16 \%$ flaxseed in the diet presented an optimal value of $64.46 \%$ of reactive sperm, that is, $64.46 \%$ of sperm had an integral plasma membrane after the freezing/thawing process, corroborating the suggests made by Watson (2000), who stated that factors that act on sperm cells, such as temperature, composition, $\mathrm{pH}$, and osmolarity of the surrounding environment, may cause irreversible alterations in their membranes. According to Bucak et al. (2010), oxidative stress contributes to poor semen quality after freezing/thawing. For these authors, the cryopreservation process caused changes in the sperm plasma membrane and resulted in decreased fecundating potential of these cells, which was reflected in damage to the plasma membrane, reduction of sperm motility, and viability, as well as interference with sperm functions.

Table 5. Hyposmotic tests and acrosomal integrity test of cryopreserved semen of male goats fed flaxseed dietary levels.

\begin{tabular}{lccccc}
\hline \multirow{2}{*}{ Tests (\%) } & \multicolumn{3}{c}{ Flaxseed Level (\%) } & \multicolumn{1}{c}{$\begin{array}{c}\text { Regression } \\
\text { equation }\end{array}$} \\
\cline { 2 - 5 } & 0 & 4 & 8 & 12 & $\hat{\mathrm{Y}}^{* *}=50.078+$ \\
Hyposmotic & $51.86 \pm 12.40$ & $55.38 \pm 9.80$ & $69.81 \pm 12.7$ & $59.52 \pm 13.6$ & $3.5246 \mathrm{x}-$ \\
Test & & & & & $0.2158 \mathrm{x}^{2}$ \\
& & & & & $\mathrm{R}^{2}=0.6496$ \\
$\hat{\mathrm{Y}}^{* *}=$ & \\
Acrosomal & & & & & $57.478+5.7851 \mathrm{x}$ \\
Integrity Test & $57.48 \pm 10.03$ & $65.53 \pm 7.70$ & $59.08 \pm 5.37$ & $61.68 \pm 5.38$ & $-1.1883 \mathrm{x}^{2}$ \\
& & & & & $0.0613 \mathrm{x}^{3}$ \\
& & & & & $\mathrm{R}^{2}=1.0$ \\
\hline
\end{tabular}

Goats supplemented with $0,4,8$ and $12 \%$ flaxseed in the diet. Data were analyzed by Regression Analysis at 5\% significance and refer to means \pm standard deviation. ${ }^{* *}$ Significant at $5 \%$ significance.

There was a significant difference in the acrosomal integrity test, showing an optimal maximum level of $3.25 \%$ flaxseed for acrosomal integrity of $65.83 \%(\mathrm{P}<0.05)$ (Table 5). According to Mies Filho (1987), the destruction of the acrosome and its lesions may be caused by aging, thermal shock, or improper manipulation of semen during processing. The acrosome may be wrinkled or badly contoured or detached. Research developed by Dolatpanah et al. (2008) demonstrated that PUFAs are responsible for the greater ability to maintain the integrity of the acrosome, whose characteristics, according to Bernardi (2008) are essential to the sperm cell, as it is an effective attribute to ensure good fertility potential of the sperm cells, regardless of species. Castellano et al. (2010), although not finding improvement in swine cryopreserved semen, found that the cryopreservation process decreased the proportion of mobile and viable sperm in the postthawed semen, as well as in acrosomal integrity, and increased DNA fragmentation and susceptibility to lipid peroxidation in relation to fresh semen, using fish oil as a source of omega-3 in the diet. Islam et al. (2006) reported differences in motility for cooled goat semen at 24 or $48 \mathrm{~h}$. Samadian et al. (2010) also considered that omega-3 sources may positively influence the 
seminal quality, and attributed the effect to the possible increase in docosahexaenoic acid (DHA) in the ejaculate.

Flaxseed, among the possible sources of dietary supplementation, is an excellent source of PUFAs and a possible alternative to increase the reproductive indexes by its composition. In the present study, flaxseed supplemented goat diets may have been responsible for the incorporation of DHA into the sperm membranes, conferring greater resistance against the freezing/thawing process and promoting improvement of important parameters.

The addition of $12 \%$ flaxseed to the diet of goat breeders improved post-thaw sperm resistance, verified with complementary tests. An optimum inclusion level was determined using the hypoosmotic test $(8.16 \%)$ and the acrosomal integrity test $(3.25 \%)$, which may contribute to better fertilization results.

\section{REFERÊNCIAS}

ABD EL-RAZEK, I.M.; ASHMAWY, T.A.M.; EL-SAIDY, B.E.; ELSHAMAA, I.S. Effect of oral fish oil supplementation on fresh and frozen ram semen quality and subsequent fertilization rates in mature ewes.

Journal Agricultural Research Kafer El-Sheikh University, v.35, n.3, p.810822, 2009.

ANSARI, M.; TOWHIDI, A.; SHAHRBABAK, M.M.; BAHREINI, $M$. Docosahexaenoic acid and alphatocopherol improve sperm cryosurvival in goat. Journal of Animal Science, v.45, p.7-13, 2012.

ASSOCIATION OF OFFICIAL ANALYTICAL CHEMISTS - AOAC.
Official methods of analysis. $15 \mathrm{ed}$. Washington, 1990.

BARROS, T.B.; TONIOLLI, R. Uso potencial da água de coco na tecnologia de sêmen. Revista Brasileira de Reprodução Animal, v.35, p.400-407, 2011.

BERNARDI, M.L. Tecnologias aplicadas no exame do ejaculado suíno para a produção de doses de sêmen de alta qualidade. Acta Science

Veterinariae, v.36, p.5-16, 2008.

BLESBOIS, E.; LESSIRE, M.; GRASSEAU, I.; HALLOUIS, J.M.; HERMIER, D. Effect of dietary fat on the fatty acid composition and fertilizing ability of fowl sêmen.

Biology of reproduction, v.56, p.12161220, 1997.

BUCAK, M.N.; TUNCER, P.B.; SARIÖZKANB, S.; BAŞPINAR, N.; TAŞPINAR, M.; COYAN, K.; BILGILI, A.; AKALIN, P.P.; BÜYÜKLEBLEBICI, S.; AYDOS, S.; ILGAZ, S.; SUNGUROĞLU, A.; OZTUNA, D. The effect of antioxidants on post-thawed Angora goat (Capra hircusancryrensis) sperm parameters, lipid peroxidation and antioxidant activities. Small Rumin Research, v.89, p.24-30, 2010.

CASTELLANO, C.A.; AUDET, I.; BAILEY, J.L.; LAFOREST, J.P.; MATTE, J.J. Dietary omega-3 fatty acids (fish oils) have limited effects on boar semen stored at $17{ }^{\circ} \mathrm{C}$ or cryopreserved. Theriogenology, v.74, n.8, p.1482-1490, 2010.

CEYLAN, A.; SERIN, I. Influence of ascorbic acid addition to the extender on dog sperm motility, viability and acrosomal integrity during cooled 
storage. Revue de Médecine

Vétérinaire, v.7, p.384-387, 2007.

CHAKRABARTY, J.; BANERJEE, D.; PAL, D.; DE, J.; GHOSH, A.; MAJUMDER, G.C. Shedding off specific lipid constituents from sperm cell membrane during cryopreservation. Cryobiology, v.54, n.1, p.27-35, 2007.

COLÉGIO BRASILEIRO DE REPRODUÇÃO ANIMAL - CBRA. HENRY, M.; NEVES J.P.; JOBIM, M.I. Manual para exame andrológico e avaliação de sêmen animal, 3 ed. Belo Horizonte, 104p, 2013.

DOLATPANAH, M.B.; TOWHIDI, A.; FARSHAD, A.; RASHIDI, A.; REZAYAZDI, A. Effect of dietary fish oil on semen quality of goats. Journal of Animal Science, v.21, p.29-34, 2008.

ISLAM, R.; AHMED, K.; DEKA, B.C. Effect of holding and washing on the quality of goat semen. Small Ruminant Research, v.66, p.51-57, 2006.

MACHADO, W.M.; BARBOSA, L.P.; SOUZA, R.S.; FRANÇA, C.S.; PINHEIRO, E.E.G.; LENTS, M.P.; ARAÚJO, R.C.S.A.; SANTANA, A.L.A. Óleo de peixe associado ao ácido ascórbico no diluidor para criopreservação de sêmen caprino. Arquivo Brasileiro de Medicina Veterinária e Zootecnia, v.70, n.1, p.131-138, 2018.

MIES FILHO, A. Inseminação

Artificial. 6 ed., Porto Alegre: Ed.

Sulina, v.2, p.434-560, 1987.

MORRIS, D.H. Methodologic challenges in designing clinical studies to measure differences in the bioequivalence of n-3 fatty acids.
Molecular and Cellular Biochemistry, v.246, p.83-90, 2003.

NRC. Nutrient Requirements of Small Ruminants: Sheep, Goats, Cervids, and New World Camelids. National Academy of Science, Washintgton, D.C. 347 p, 2007.

PIMENTEL, C.V.M.B.; FRANCKI, V.M.; GOLLÜCKE, A.P.B. Alimentos funcionais: introdução as principais substâncias bioativas em alimentos. São Paulo: Ed. Varela, 95p, 2005. PURDY, P.H. A review on goat sperm cryopreservation. Small Ruminant Research, v.63, p.215-225, 2006.

SAMADIAN, F.; TOWHIDI, A.; REZAYAZDI, K.; BAHREINI, M. Effects of dietary n-3 fatty acids on characteristics and lipid composition of ovine sperm. The Animal Consortium, v.4, n.12, p.2017-2022, 2010.

SEVERO, N.C. Influência da qualidade do sêmen bovino congelado sobre a fertilidade. A Hora Veterinária [on line], 28. Jan-Fev, 2009.

SILVA, A.F.; COSTA, E.P.; OLIVEIRA, F.A.; TORRES, C.A.A.; HASS, G.T.S.; NASCIMENTO, V.A. Uso de dimetil-formamida associada ou não ao glicerol na criopreservação de sêmen caprino. Revista Brasileira de Zootecnia, v.35, n.2, p.452-456, 2006.

SILVA, S.V.; GUERRA, M.M.P. Efeitos da criopreservação sobre as células espermáticas e alternativas para redução das crioinjúrias. Revista Brasileira de Reprodução Animal, v.35, p.370-384, 2011.

SUDHEERA, S.D.; JAMES, W.L.;

FALCONER, L.; GARG, M.L.

Prevention of cardiac arrhytmia by 
dietary (n-3) polyunsaturated fatty acids and their mechanism of action. The

Journal of Nutrition, v.127, n.4, p.383-393, 1997.

THOMPSON, L.U.; ROBB, P.; SERRAINO, M.; CHEUNG, F. Mammalian lignin production from various foods. Nutrition and Cancer, v.16, p.43-52, 1991.

VAN SOEST, P.J.; ROBERTSON, J.B.; LEWIS, B.A. Methods for dietary fiber, neutral detergent fiber, and non starch polyssacharides in relation to animal nutrition. Journal of Dairy Science, v.74, p.3583-3597, 1999.

WATSON, P.F. The causes of reduced fertility with cryopreserved semen.

Animal Reproductions Science, v.60, n.61, p.481-492, 2000. 